\title{
THE ROLE OF TECHNICAL INNOVATION AND DEVELOPMENT OF INDUSTRIAL SECTOR IN KOREAN INTERNATIONAL BUSINESS
}

\author{
Ali Mohammed Khalel Al-Shawaf \\ Uruk University
}

Tahira Yasmin*

Al Ain University

\begin{abstract}
With the pace of development and competitiveness, innovation plays an important role to capture the market share. Various countries have effective strategies to enhance Research and Development (R\&D) and exchange value added products in international market. So, based on this the aim of this research is to examine the role of $\mathrm{R} \& \mathrm{D}$, industrial design and charges for intellectual property in innovative exports in South Korean economy. Time series data for the period 1998 to 2017, Ordinary Least Square (OLS) and Generalized Method of Moments (GMM) models are used to determine the dynamic interrelationship among the study variables. In summary, the overall results show that there is co-integration rank of in both trace test and value test at $1 \%$ significance level. Moreover, OLS and GMM findings depict that there is significant and positive coefficient for ID \& RD which represent that they have positive impact on HT. Whereas, the IP displays a negative and significant relationship with high technology exports accordingly. Lastly, the diagnostic tests show that model is stable for the study time period and result is reliable. The current study also suggests some policy implications which can enhance innovative export products of South Korea while enhancing R\&D.
\end{abstract}

Keywords: Innovation; Research and Development (R\&D); Industrial Design; High Technology Exports; Charges for the use of Intellectual Property; South Korea.

Received: 19 December 2019

Accepted: 31 December 2020

https://doi.org/10.33736/ijbs.3162.2021

\section{INTRODUCTION}

In today's business world there are various international business challenges such as laws and regulations; universal payment methods; exchange rate and international accounting (see Ershova, 2017; Lhermie, Tauer, \& Gröhn, 2018; Putzhammer, Slangen, Puck, \& Lindner, 2019; Zhu, Zheng, Zhang, \& Guo, 2019; Deligonul, 2020). So, to capture market share and be successful countries are having huge investment in Research and Development (R\&D). The vast general censuses believe that $R \& D$ plays a vital role in the competitiveness of a country or region, as it is a key driver in innovation process. Furthermore, it is estimated that not only innovation is a costly process but it also depends on regional capacities, readiness to change and allocative financial

-Corresponding author: Assistant Professor, Al Ain University, P.O. Box: 64141, Al Ain, UAE; Tel: +971-37024819; Fax: +97137024777; Email: tahira.yasmin@aau.ac.ae 
plans. In addition, there is another aspect of $R \& D$ where countries direct invest in innovation such as; acquisition of new technology, purchase of advance machinery, possession of patents and new product developments (Kishi, 2019). Technical innovation is a continuous process and it enhance economic growth and generates various financial benefits but at the same time it required government attention to have steady growth plans (Maradana, Pradhan, Dash, Zaki, Gaurav, Jayakumar, \& Sarangi, 2019). This point of view is supported by (Pradhan, Arvin, Nair, Bennett, Bahmani, \& Hall, 2018), as their findings demonstrate that financial development and innovation are both causative factors of long term growth. While, Bernier and Plouffe (2019) also support the idea that financial innovation generates gross capital formation in panel of 23 economies.

A number of studies have investigated the dynamics between innovation and financial development but indeed a difference can be observed from some of the studies which found alternate results. de Oliveira, Basso, Kimura, and Sobreiro (2018) analyzed the innovation impact and business performance of Brazilian companies. They came with the results that efforts in innovation may lead to development of new product but it might not contribute in financial gains. This also reflects risk and cost element in innovation process in developing economies. Moreover, García-Quevedo, Segarra-Blasco, and Teruel (2018) indicated that some financial obstacles have negative impact on innovation projects. There is another important aspect that financial sources change with the project innovation life cycle.

From a policy point of view, disentangling the internal and external factors that influence type of innovation is critical. Pérez, Geldes, Kunc, and Flores (2019) shed light on this point that in Chile, technical innovation is driver whereas in Peru, it is non-technical innovation. Usually small businesses increase non-technical innovation by investing in workforce to manage social networks. Our study is taking into consideration the important aspect discussed by Coad and Vezzani (2019) that many industrialized countries in Europe have faced steady decline. But one of the vital point they highlighted that manufacturing sector value added lead to higher R\&D intensity as compare to non-manufacturing. This process of technology follows by another important aspect known as charges for the use of intellectual property. Korean economy has various measures in this aspect to promote innovation capacity as industrial value added. Country has bilateral and multilateral cooperation in patents; funds in trust appropriate technologies and intellectual property system to encourage trademarks and patents. Moreover, the intellectual property works as competitive advantage and use as intangible assets which further strengthen industry (Patel, Guedes, Soares, \& Gonçalves, 2018; Singhai, 2019; Kukharskyy, 2020).

Based on the background discussion, Korean economy has become more concentrated in various manufacturing industries, while interconnected has risen through vertical relationships. At the same time, the international trade has increased with enhanced global value chains (IMF, 2019a). There is also turmoil in China's trade market and it has major impact on South East Asian value chains. In addition, deleveraging in the household sector in the Republic of Korea played a role in limiting economic growth. So, it was estimated growth fell from 3.1 per cent in 2017 to 2.7 per cent in 2018, and further presumed that it will fell as 1.9 per cent in 2019 (UNCTAD, 2019a).

Despite all these challenges, South Korea stands as top innovative country and this rigorous technical innovation has measured based on productivity, high-tech public company density, research and development spending, patent activity, manufacturing output and tertiary efficiency. Furthermore, the value added of ICT sector specifically manufacturing sector is prominent in 
Republic of South Korea (UNCTAD, 2019b). All these facts motivates to investigates whether an increase in $\mathrm{R} \& \mathrm{D}$, industrial design and charges for intellectual property is promoting innovative exports in South Korean as tool of international trade or not? To address this, we develop an OLS and GMM co-integration model based on research variables to achieve the desired objective. We suppose that, Korea has various effective strategies to promote innovation but still there are various challenges of work force productivity and diversification process. Usually, the process of technology diffusion generate long term benefits with effective public financial policies and support. Furthermore, we suppose that industrial design is related to patents and trademarks and this can help any form to develop a product equipped with the new frontier technology.

The remainder of this paper is organized as follows: Section 2 provides a brief overview of the Korean context, and Section 3 discusses relevant previous studies. The fourth section presents the data and methodology; Section 5 explains results analysis and finally followed by conclusions and policy implications in Section 6.

\section{KOREAN CONTEXT}

The main objective to write this section is to shed light on various dimensions of specific elements in Korean economy. This will help the reader to understand regarding further result discussion and relevant policies. With timely economic plans and some effective initiatives Korean economy has turned into high income. Country has experienced remarkable success in combining rapid international business growth with significant reductions in poverty. Figure 1, shows that Korean economy GDP per capita and productivity is getting narrowed. There are various measures required in this context particularly in the service sector. It is important to reduce the regulatory burden on economic activity because restrictive product market regulations hinder competition and productivity gains. Government has taken another initiative to reduce working hours and introduced training programs specifically aimed for older workers. Another initiative to reduce productivity growth is to narrow the wage gap between regular and non-regular workers. In this context, Korean government is trying to transform the contracts of 205000 non-regular workers in the public sector to regular status by 2020 . 
Figure 1: Gap between GDP per capita and productivity.

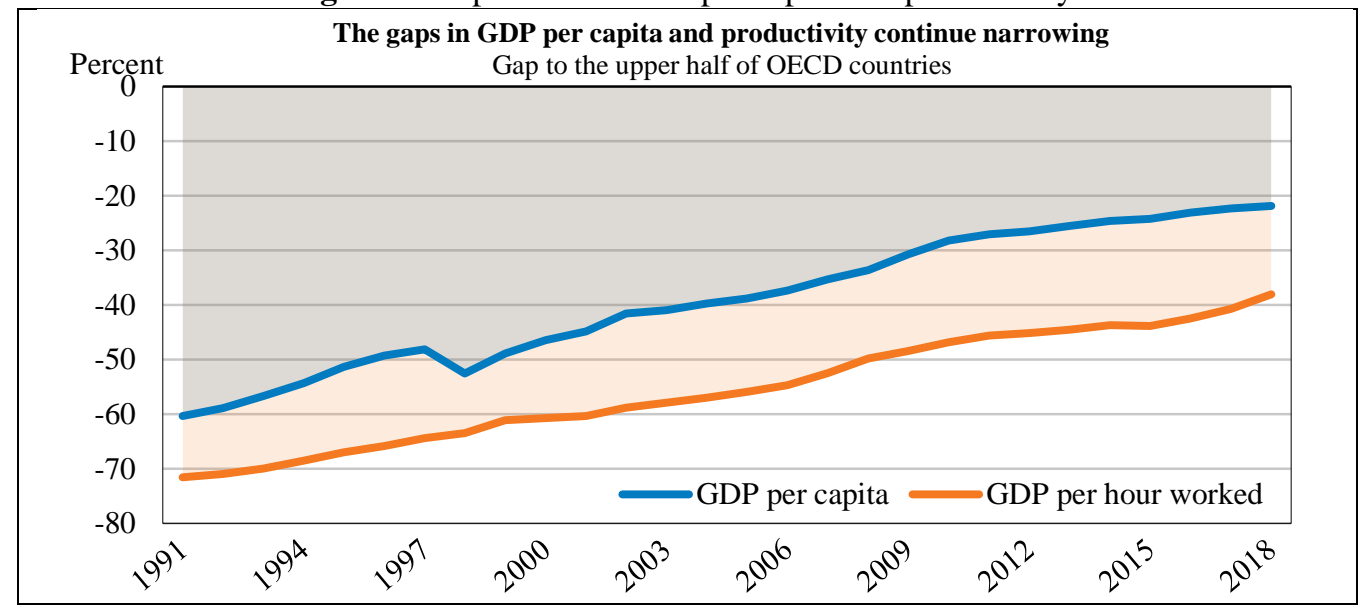

Source: Organisation for Economic Cooperation and Development (OECD), (2019).

South Korea has emerged as one of the leading manufacturing economy and remain competitive in the era of Fourth Industrial revolution named as, "Industry 4.0". This entails to convergence of digital technologies and manufacturing industries. But in Korea the automation and data exchange is known as, "Manufacturing Industry Innovation 3.0”. In June 2014, this strategy was introduced as part of Korea's Creative Economy Initiative and urging various businesses to adopt computerizing manufacturing. Figure 2 displays that services and industrial sectors have high value-added share in GDP. The increasingly share of services are being delivered both within and across the borders digitally. Korean economy has adopted this trend is more likely to connect more people with internet and enhance digital trade with rest of world. In addition, a number of different trends in industry are also affecting manufacturing technology such as cyber-physical systems, sensors and nanomaterials which are improving performance and lowering the cost. In 2018, Korea accounted for roughly $4.1 \%$ of all installed additive manufacturing systems in the world and has the third largest number of machines in the Asia-Pacific region (Export.gov, 2019).

Figure 2: Sectoral Value-Added Share in GDP.

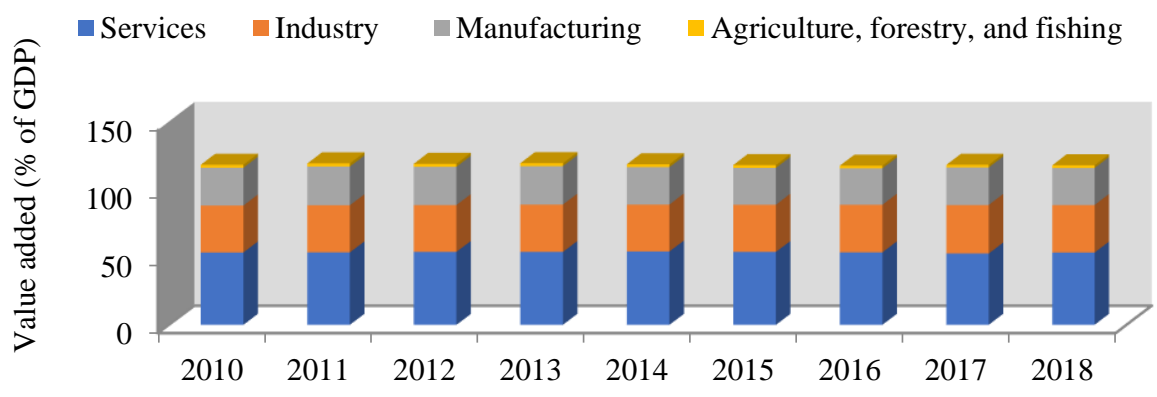

Source: World Bank Database (2019). 
Moreover, looking the sectoral value added another important dimension which current study is considering is the research and development expenditures and high technology exports. Figure 3 shows that South Korea is a technology driven economy and there is increased share of R\& D in GDP. There is utmost attempt to have high position in research and development and as well as a reference market for high-tech and lifestyle products throughout Asia. For the last five years the exports have increased at an annualized rate of 1.2\%, from \$561B in 2012 to \$596B in 2017. Moreover, the most recent exports are led by Integrated Circuits which represent $17.5 \%$ of the total exports of South Korea. But there was downward trend during 2017 due to downturn in chip market mainly as US-China trade war casts uncertainty over the technology sector. But analysts have forecasted that a recovery by end of 2019 as there are ongoing efforts to worked through high inventories. Due to declined domestic demand the South Korean government will spend S\$4.7 trillion (US\$3.9bn) of its 2020 budget on technologies such as artificial intelligence (AI), in a bid to boost R\&D, infrastructure and international trade (Hunt, 2019).

Figure 3: R\&D Expenditures and technical oriented exports.

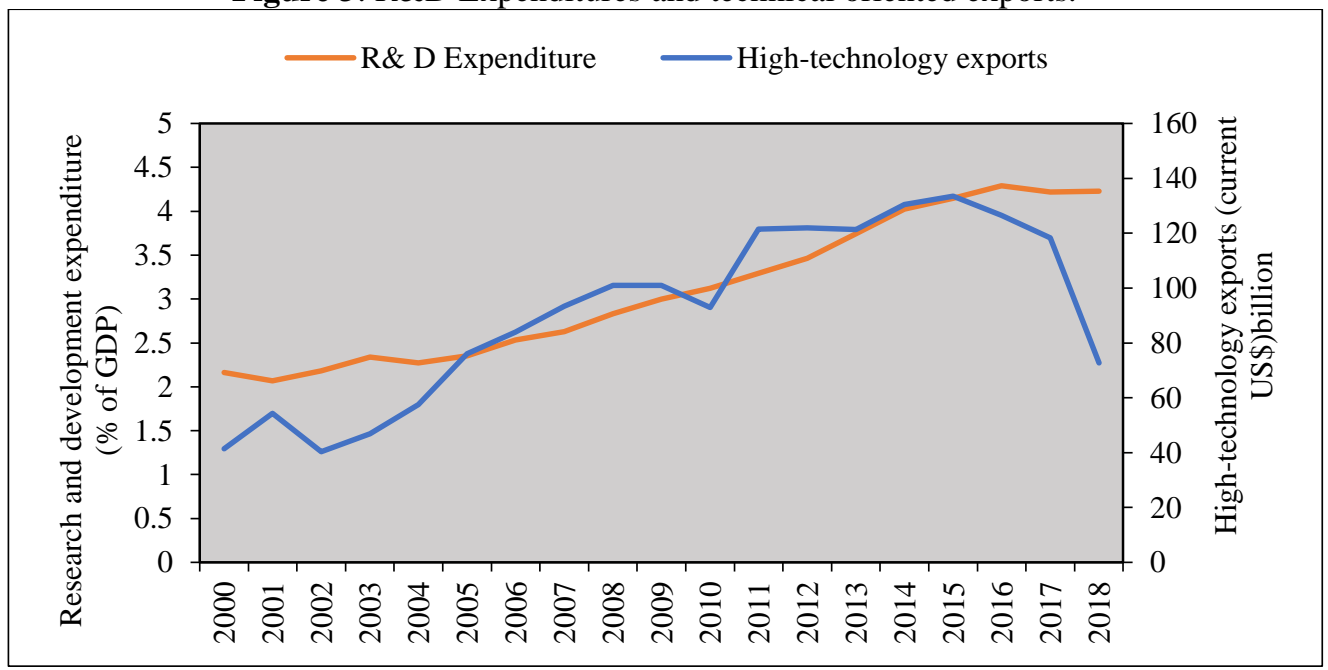

Source: World Bank Database (2019).

In summary, it is interesting to study South Korean business activities due to its prominent position in world market as technology hub. Country is getting benefits as platform for international trade fairs as one way of entering market. Furthermore, the technical affinity reflected not only in its leading broadband technology but also e-commerce has outstripped conventional sales channel. Korea ranked $5^{\text {th }}$ in, "Ease of Doing Business 2019" index due to have fast and cost effective business set up. Overall, South Korea strengthened its position in export market as many countries are enjoying benefits with free trade agreement. 


\section{RELATED LITERATURE REVIEW}

In the modern concept of innovation and development, Schumpeter (1934) has leading role despite some of the difficulties suffered as formal representative of innovation. He elaborated the concepts of endogenous innovation and industrial maturity as contrasted to the mechanical view of his fellow econometricians. Based on such foundations, Maclaurin (1946) stated that even economists have long interest in technical change but there has been limited investigation regarding the factors influence the technical change process in specific industries. He identified four factors leading to technical change in industry since nineteenth century such as: capabilities in research and product engineering; degree of competition; demand and alternative technologies. After few years, he suggested that technical innovation is a continuous process comprised on various stages as: fundamental research; applied research; engineering development and production engineering (Maclaurin, 1950).

Following on there were other two models of innovation specifically known as liner and sequential model of innovation. Godin also argued that Maclaurin constructed one of the first taxonomies for measuring technological innovation. The innovation diffusion has obvious analogies with the sequence from anthropology. Another important aspect is that borrowing from anthropology or independent and parallel invention is difficult to determine (see Godin, 2006; 2008; 2011). Further, innovation was elaborated in another aspect as economic policy eclipsing the broader anthropologists. This also leads from innovation to diffusion process and giving privileged to researchers agendas (Godin, 2002; 2010; 2012).

A great deal of literature is devoted to study innovation and $R \& D$ process and its effects on growth, exports and manufacturing sector. In export oriented innovation literature, Rodil, Vence, and Sánchez (2016) examined the relationship between innovation and export behavior at firm level. The study combined various variables such as: research and development; innovation; structural characteristics and export behavior of firms. Overall, positive relationship was found between innovation and exports but variety of innovation and marketing innovation are critical factors. Further, the effects of innovation has been also investigated by Dai, Sun, and Liu (2018) on firm level mark-up using large sample of Chinese manufacturing firms through propensity score matching approach. They found complementary relationship between export and innovation in improving firms' performance. The result suggested that it is vital that firms should develop domestic power by having technical innovation. These findings are in the same line with some other studies which also examined the export oriented FDI and technology spill over effect (Makri, Theodosiou, \& Katsikea, 2017; Ghosh, Morita, \& Nguyen, 2018; Pradhan, Arvin, \& Bahmani, 2018).

This paper relates to (Kishi, 2016) in methodology aspect, who applied OLS approach regarding firm's relative productivity by frontier technology. He argued that the firm's productivity can attain the new frontier level if the firm succeeds in an innovation and this mechanism generates a Pareto distribution of the firm's productivity with bounded support. Furthermore, another aspect is that innovation size also follows Pareto distribution with no support from upper bound. But current study is focusing on industrial design as a proxy of innovation in Korean economy. 
Azar and Ciabuschi (2017) tested the innovation and export hypotheses by structural equation modelling on the relationship between different types of technical innovation and firm export performance in 218 Swedish firms. The main findings indicated that innovation led to high export performance as directly and indirectly. In another study, Gkypali, Arvanitis, and Tsekouras (2018) developed a unified framework between three major components as diversity, innovation and export performance. They employed Structural Equation Modelling on a sample of Greek R\&D active manufacturing firms. The main findings suggested that small firms had low innovation dynamics due to financial constraints and internationalization barriers. Bodlaj, Kadic-Maglajlic, and Vida (2018) indicated that innovation and export led diversification also generate benefits for SMEs. Buryi and Lahiri (2019) developed a theoretical model by having two policy instruments as; matching grants and import tariffs to promote research and development for local firm innovation when it face foreign competition. Whereas, Silva, Gomes, and Lages (2019) analyzed the extent to which the importer's involvement can influence the product innovation. Culture and learning process plays an important role in innovation process and it also differs regionally. Švarc, Lažnjak, and Dabić (2019) explained the impact of various regional cultures and innovation capacities in the light of Hofstede's model in Croatian regions. They found that there was no correlation between regional cultures and innovation capacities.

Huang and Hou (2019) used data from Taiwanese manufacturing firms for the 2000-2015 period. The study employed system-generalised method of moments and result revealed that innovative firms have far more profit as compare to non-innovative firms. Moreover, the study indicated that the firms which invest in research and development gain more profitability. Štěrbová, Stojanovski, Weiss, and Šálka (2019) shed light on innovation process in forestry sector in Slovakia and Macedonia. They came with an interesting point that personal characteristics of innovators are fostering elements in innovation process in both countries. Furthermore, institutional and economic frameworks also facilitate the implementation of innovation process.

Korean economy is an interesting case study for many researchers from technical innovation aspect. Larson and Park (2014) examined Korea's remarkable technical development strategies while looking economic transformation process and boom of various industries. At the same time they have highlighted that the Korean development lies in network state but they suggested the value of technically trained leaders in ICT. It was also emphasized to promote education and specialized R\&D to broadly public-private sector to ensure demand for service. Whereas, Seo and Joo (2019) shed light on very sensitive point in South Korea that what actually triggers district governments to commit to initiate and sustain governance innovation is highly subject to the funds availability from national government. This point was further justified by Nuruzzaman, Singh, and Pattnaik (2019), they examined the effect of increased competition in international and domestic markets. They found that strong government ownership and legal rights can moderate the relationships between imitative innovation and exposure to foreign competition in home country.

Holcombe (2013) believed that Korean economic success lies in competitive industrial sector in world market. As there is widespread sentiment to emphasize on industrial policy, others believe that industrial policy has generated benefits at the expense of working class Koreans. Author suggested that neither industrial policy nor economic democracy are in best interests of Korea but minimal government interference will provide the best environment to foster economic growth. Related to process and product innovations in Korea, Lim and Lee (2019) analyzed this aspect under different market structures in manufacturing firms. They came with an important conclusion 
that product innovation have positive and significant impact on employment whereas process innovation has greater negative effect in monopolistic markets.

The raising research and development expenditures in manufacturing firms has increased in Korea since 1980s. Branstetter and Kwon (2018) argued that due to increase in external market demand there is significant impact on research development expenditures of manufacturing firms. The panel data analysis from 1981 to 1995 showed that exchange rate change was a significant driver of increased R\&D expenditures due to causal relationship between both of them. In another study by Doh and Kim (2014) examined the impact of government subsidy on innovation of regional SMEs. The study found positive relationship between government support and patent acquisition. This means that South Korean government should design long term policies for financial support to have better innovation process.

Kim, Shin, and Lee (2019) study is different from previous studies as they used efficient ratio for of R\&D investment for basic, applied, and development research. The empirical analysis estimated the optimum ratio of financial source type according to public and private R\&D. The result highlighted an interesting fact that Korea's R\&D investment as share of GDP is highest in the world but public $R \& D$ ratio is still relatively low and it needs to be adjusted.

Industrial policy as primarily involving investment and technology is another important aspect in Korean economic growth. Lechevalier, Debanes, and Shin (2019) analyzed the revival of industrial policies since 2000 in Korean and Japanese economies. Various complementarities between industrial policies and financial mobilization allowed Japan and Korea to catch up with European economies. However, in the long term it has resulted in macroeconomics imbalances and reversing the hierarchy between state and the financial system. By comparison of both economies, it was found that loss of institutional capabilities is deeper in Japan due to difference in institutional features and pace of change. While, Choi, Narasimhan, and Kim (2016) analyzed a series of feedback causal relationship by system dynamics simulation in order to disclose the hidden innovation mechanism in Korean electronic industries. They found that R\& D creates new knowledge and triggers interaction among other technical entities.

Overall, the analysis of the above-mentioned studies generates two interesting observations. First, the hypothesis of strong dependency of economic growth due to export led innovation. Secondly, the role of government in financing innovation process and putting rules and regulations in the market. To fill this gap, the current study will investigate the innovation mechanism in Korean economy by underlying industrial design application and research and development expenditures to reveal the role in technical innovative exports. This research has tried to shed light on a vital aspect in Korean economy that revealed the outlook of manufacturing industries as innovative exports. Previous studies have elaborated many aspects in Korean economy buy current study examine the the aspect of intellectual property and innovation together in this country because of high productivity as one of the core values in manufacturing sector. Even the landscape has changed but Korea still offers interesting opportunities in manufacturing sector by using latest technologies. 


\section{DATA SOURCE AND METHODOLOGY}

\subsection{Data Sources}

This section describes the data sources that used to examine the relationship between high technology export, industrial design application, research and development expenditure (\% of GDP) and charges for the use of intellectual property rights (see Table 1). Current study utilized annual data transformed in log which consists of from 1998 to 2017 period. Micro-fit version 5.0 and eviews version 10 statistical packages are utilized to analyze the relationship among these variables.

Table 1: Data Sources and research variables.

\begin{tabular}{|c|c|c|c|c|}
\hline Variable & Description & $\begin{array}{l}\text { Unit of } \\
\text { measurement }\end{array}$ & Source & "Definitions of Variables \\
\hline HT & $\begin{array}{l}\text { High } \\
\text { technology } \\
\text { export } \\
\text { products }\end{array}$ & Million USD & $\begin{array}{l}\text { World Bank } \\
\text { Database }\end{array}$ & $\begin{array}{l}\text { High technology exports are } \\
\text { products with high R\&D } \\
\text { intensity, such as in aerospace, } \\
\text { computers, pharmaceuticals, } \\
\text { scientific instruments, and } \\
\text { electrical machinery. }\end{array}$ \\
\hline ID & $\begin{array}{l}\text { Industrial } \\
\text { design } \\
\text { applications } \\
\text { the proxy } \\
\text { for } \\
\text { Innovation }\end{array}$ & $\begin{array}{l}\text { Total number } \\
\text { Industrial } \\
\text { design } \\
\text { applications in } \\
\text { South Korea }\end{array}$ & $\begin{array}{l}\text { World Intellectual } \\
\text { Property } \\
\text { Organization } \\
\text { (WIPO ) }\end{array}$ & $\begin{array}{l}\text { Creation and development of } \\
\text { concepts and specifications aimed } \\
\text { at optimizing the functions, value, } \\
\text { and appearance of products, } \\
\text { structures, and systems. }\end{array}$ \\
\hline R\&D & $\begin{array}{l}\text { Researchers } \\
\text { in Research } \\
\& \\
\text { developmen } \\
\mathrm{t}\end{array}$ & $\begin{array}{l}\text { Research and } \\
\text { development } \\
\text { expenditure (\% } \\
\text { of GDP) }\end{array}$ & $\begin{array}{l}\text { The United } \\
\text { Nations } \\
\text { Educational, } \\
\text { Scientific and } \\
\text { Cultural } \\
\text { Organization }\end{array}$ & $\begin{array}{l}\text { Gloss domestic expenditures on } \\
\text { research and development } \\
\text { (R\&D), expressed as a percent of } \\
\text { GDP. They include both capital } \\
\text { and current expenditures in the } \\
\text { four main sectors: Business } \\
\text { enterprise, Government, Higher } \\
\text { education and Private non-profit. } \\
\text { R\&D covers basic research, } \\
\text { applied research, and } \\
\text { experimental development. }\end{array}$ \\
\hline IPR & $\begin{array}{l}\text { Charges for } \\
\text { the use of } \\
\text { intellectual } \\
\text { property }\end{array}$ & US Dollars & $\begin{array}{l}\text { World Intellectual } \\
\text { Property } \\
\text { Organization }\end{array}$ & $\begin{array}{l}\text { Charges for the use of intellectual } \\
\text { property are payments and } \\
\text { receipts between residents and } \\
\text { non-residents for the authorized } \\
\text { use of proprietary rights (such as } \\
\text { patents, trademarks, copyrights, } \\
\text { industrial processes and designs } \\
\text { including trade secrets, and } \\
\text { franchises). }\end{array}$ \\
\hline
\end{tabular}




\subsection{Model Specification}

In order to examine the log run relationship between research variables as HT, ID, R\&D and IPR we conducted simple ordinary least square (OLS) regressions. Muhammad and Khan (2019) used OLS approach to investigate the contributing economic factors in Asian economies whereas, Boateng, Hua, Nisar, \& Wu (2015) explored the FDI determinants in Norway. So, current study investigate the relationship among research variables in linear form as in equation (1).

$$
H T_{t}=\mu+\beta_{1} I D+\beta_{2} R D+\beta_{3} I P R+\varepsilon_{t}
$$

where $\mu$ is the intercept; $\mathrm{t}$ is the time; while $\varepsilon$ stands for residual term or standard error that is assumed to be normally distributed and $\beta$ s are the coefficients of variables. Since, all the variables transformed in to natural logarithms $(\mathrm{L})$. This technique is more appropriate to generate efficient results as compare to simple linear model. Not only this, it also reduces the risk of hetrosecedasticity problem and obtains the growth rate of the variable (Bekhet, Othman, \& Yasmin, 2020).

It is argued by many researchers that if time series data is not stationary then regression analysis will not be an appropriate true measure (Bekhet \& Al-Smadi, 2016; Bekhet \& Mugableh, 2012; Gujarati \& Porter, 2008). The Johansen and Juselius (1990) co-integration tests used for all the variables in order to see the existence of co-integration among the variables. In this aspect, the maximum eigenvalue and trace value is compared with its critical value, if trace value is more than its critical value, $\mathrm{H}_{0}$ is rejected, no co-integration rejected (Brooks, 2008).

Johansen and Juselius (1990) discussed that the behaviour of long-run and short-run relationship could be explained through the co-integration technique. This is based on the assumption that all the indicators of the series are stationary in the same order at $I(1)$ or $I(2)$. The Johansen and Juselius test is indicated by equation 2 and 3 . For trace test the following equation provides a test of null hypothesis, $\mathrm{H}_{0}: \mathrm{r} \leq \mathrm{r} 0$ where, $\mathrm{r} 0=\mathrm{n}-1$. Alternate hypothesis, $\mathrm{H}_{1}: \mathrm{r}>\mathrm{r} 0$, Whereas,

$$
l_{\text {trace }}=-T \sum_{i=r+1}^{n} \ln \left(1-\lambda_{i}\right)
$$

Where, $r=$ the number of co-integrating vectors, $\mathrm{T}=$ sample size, $\ln =$ natural logarithm, $\lambda_{i}=$ estimated value of ordered eigenvalue. When the trace value is compared with its critical value, if trace value is more than its critical value, $\mathrm{H}_{0}$ is rejected, no co-integration rejected (Hjalmarsson \& Österholm, 2007; Brooks, 2014). Whereas, the maximum eigenvalue test provides a test of null hypothesis, $\mathrm{H}_{0}: \mathrm{r}=\mathrm{r} 0$. Alternate hypothesis, $\mathrm{H}_{1}: \mathrm{r}+1$ as in equation (3),

$$
l_{\text {max }}=-T \ln \left(1-\lambda_{r+1}\right)
$$

Where, $r=$ the number of co-integrating vectors. If $r=$ number of indicators used, none of the series are integrated. When the maximum eigenvalue value is compared with its critical value, if the maximum eigenvalue is more than its critical value, $\mathrm{H}_{0}$ is rejected, accept $\mathrm{H}_{1}$ co-integration accepted (Hjalmarsson \& Österholm, 2007; Brooks, 2014). 


\section{RESULTS AND DISCUSSION}

To check the data quality the descriptive statistics are shown in Table 2 that all the variables are positively and significantly interrelated with each other. Moreover, the result from diagnostic tests displays that there is no problem of autocorrelation and the data series are normally distributed. So, it can conclude that result from both normality and auto correlation are reliable, since the t-statistics, probability and Jarque-Bera are greater than t-critical value in $5 \%$ level. Also, for the result of Rsquared indicate the model has significant fitting in general. Further, the results confirmed that the data is homoscedasticity and indicated that the model used is well fitted. Specifically, the ECMt1 coefficient value between other models with $-76 \%$. This indicates that the $\Delta \mathrm{HTt}$ model is corrected from the short-run towards the long-run equilibrium by $76 \%$ or the long-run equilibrium among HT, and other variables would be shortly corrected back by one and half year (one divided by the estimated coefficient of ECMt-1).

Table 2: Descriptive and Diagnostic Tests.

\begin{tabular}{lcclc}
\hline \hline & LHT & LID & LRD & LIPR \\
\hline Mean & 25.1413 & 8.1351 & 1.1162 & 21.4916 \\
Maximum & 25.6169 & 8.7898 & 1.4559 & 22.6599 \\
Minimum & 24.1551 & 7.3639 & 0.725914 & 19.3819 \\
Std. Dev & 0.4603 & 0.4578 & 0.2655 & 0.9284 \\
Diagnostic Test & & Probability & & \\
Autocorrelation (Breusch- & & & \\
Godfrey Serial Correlation LM & 0.4236 & & \\
Test) & & 0.6566 & & \\
Histogram Normality Test & 0.8811 & & \\
Heteroskedasticity Test: ARCH & 0.9058 & & \\
R-squared & & 0.8924 & & \\
Adjusted R-squared & 0.0000 & P-value & Prob. \\
F-statistic & Error & $2.9753^{*}$ & 0.0100 \\
DV(HT) & Coefficient & 0.2569 &
\end{tabular}

Whereas, the results of the Augmented Dickey-Fuller (ADF) and Phillips-Perron (P.P) tests as highlighted in Table 3, depicts that the variables are tested at level I(0) and first difference I(1) with the inclusion of intercept, followed by another with intercept and trend. The ADF and PP tests results concluded that all the variables are stationary at I(1) at $10 \%$ and $5 \%$ respectively.

Table 3: Unit Root Test.

\begin{tabular}{|c|c|c|c|c|}
\hline & \multicolumn{2}{|c|}{ ADF } & \multicolumn{2}{|c|}{$\mathbf{P P}$} \\
\hline & $I(0)$ & $I(1)$ & $I(0)$ & $I(1)$ \\
\hline Indicators & Intercept & Intercept \& trend & Intercept & Intercept $\&$ trend \\
\hline LHT & $-3.8867 *$ & $-3.2977 * * *$ & $-3.8867^{*}$ & $-4.6162 *$ \\
\hline LID & $-3.8867 *$ & $-3.7332 * *$ & $-3.8867 *$ & $-4.6162 *$ \\
\hline LRD & $-3.8867 *$ & $-3.7104 * *$ & $-3.8867 *$ & $-3.7104 * *$ \\
\hline LIPR & -2.5609 & $-1.9684 * *$ & $-3.8573 *$ & $-4.5715^{*}$ \\
\hline
\end{tabular}

Note: $* * *, * *, *$ Indicates significance at the $10 \%, 5 \%$ and $1 \%$ level respectively. 
These results confirm that all the variables were consistently stationary at I(1). Thus, these findings suggested that the null hypothesis of unit root tests for both ADF and PP test are rejected and it is possible to proceed to the co-integration test (see Al-Shawaf \& Almsafir, 2016; Bekhet \& AlSmadi, 2016; Bekhet, Matar, \& Yasmin, 2017). However, as in Dizaji (2014), if we rely on the results of the Phillips-Perron (PP) test since the PP is considered to have a greater statistical reliability than the $\mathrm{ADF}$ due to its robustness in the midst of serial correlation and hetersokedasticity (Elliot, Rothenberg, \& Stock, 1996), we can infer that all the variables are nonstationary and integrated of order 1$)$.

A step ahead, Table 4 provides the empirical results from Johansen cointegration test, it shows that both the trace tests and maximum-eigen reject the null hypothesis of co-integration at the $1 \%$ significance level according to critical value estimates. The result also shows a co-integration rank of one in both trace test and value test at $1 \%$ significance level.

Table 4: Unrestricted Co-integration Tests.

\begin{tabular}{ccccc}
\hline \hline & \multicolumn{4}{c}{ Rank Test (Trace) } \\
\hline Hypothesized & Eigenvalue & Trace & $\mathbf{0 . 0 5}$ & Prob.** \\
NO. of CE(s) & \multicolumn{5}{c}{ Statistic } & 47.8561 & $0.0001^{*}$ \\
None * & 0.9173 & 69.6546 & 29.7970 & 0.6183 \\
At most 1 & 0.3937 & 17.2938 & 15.4947 & 0.6031 \\
At most 2 & 0.1799 & 6.7824 & 3.8414 & 0.1058 \\
At most 3 & 0.1171 & 2.6154 & $\mathbf{0 . 0 5}$ \\
\hline \multicolumn{5}{c}{ Rank Test (Maximum Eigenvalue) } \\
\hline Hypothesized & \multicolumn{5}{c}{ Trace } & Critical Value & Prob.** \\
NO. of CE(s) & Eigenvalue & Statistic & 28.5880 & $0.0000^{*}$ \\
None * & 0.9263 & 54.7797 & 22.2996 & 0.2216 \\
At most 1 & 0.5590 & 17.1955 & 15.8921 & 0.5637 \\
At most 2 & 0.3124 & 7.8668 & 9.1645 & 0.5034 \\
At most 3 & 0.1507 & 3.4311 & \\
\hline \hline
\end{tabular}

Note: Trace and Maximum Eigenvalue Tests indicates 1 co-integrating equation (s) at the 1\%; * denotes rejection of the hypothesis at the $5 \%$ level of significant.

After getting the result of co-integration, we further proceed to a step ahead to examine the relationship between research variables. Table 5 shows the result of the Ordinary least squares (OLS) and displays that there is significant and positive sign of coefficients for ID \& RD represent that they have positive impact on HT. Whereas, the IPR displays a negative and significant relationship with high technology exports accordingly. This negative relationship might display that sometimes strong intellectual property rights does not contribute in innovation (Hu \& Mathews, 2005). Furthermore, this also confirms that that IPRs were not significant drivers of technological advancement and that in fact also justified by previous studies (see Acemoglu, Gancia, \& Zilibotti, 2012; Cimoli, Fleitas, \& Porcile, 2013; Auriol, Biancini, \& Paillacar, 2019). Moreover, Jiyoung, Chulyeon, and Gyunghyun (2019) also mentioned that efficiency of R\&D increase with the innovation intensity in small and medium enterprises in Korea. They suggested that firms should integrate the R\&D outputs into their own innovation process which requires absorption capacity by incorporating innovation capability. In context of industrial designs there is vital suggestion provided by (Lechevalier et al., 2019) is that due to state contradictions the development weekend and it leads to restructuration of state capabilities to design and implement industrial policies. Table 
5 shows that ID and RD have positive and significant at 5\% level, while IPR has negative and significant relationship with HT based on OLS model. These findings attributed in the context of Korean economy, where it is well known fact that when governments adopt a deliberate and long term focus on innovation and use intellectual property as powerful strategy it turns into country's strength. Furthermore, in context of IPR as it displayed and negative coefficient, this was suggested by (Archibugi \& Filippetti, 2013) that global IPR regime and their potential is not only to promote innovation but it can also enable diffusion process. Barbu and Militaru (2019) mentioned that there is growth of formal intellectual property rights in manufacturing sectors just to prevent the competition. Moreover, the intellectual property rights lead to new ventures and competitiveness.

Table 5: OLS and GMM Results.

\begin{tabular}{lclll}
\hline \hline \multicolumn{5}{c}{ Ordinary Least Square (OLS) } \\
\hline Variable & Coefficient & Std. Error & t-Statistics & Probability \\
C & 17.7471 & 1.5080 & 11.7686 & 0.0000 \\
IPR & -1.3410 & 4.4711 & -2.9864 & $0.0087^{*}$ \\
ID & 0.7684 & 0.2195 & 3.5008 & $0.0030^{*}$ \\
RD & 1.3846 & 0.4150 & 3.3361 & $0.0042^{*}$ \\
Generalized Method of Moments (GMM) & & & \\
C & 17.7471 & 1.4830 & 11.9667 & 0.0000 \\
IPR & -1.3410 & 2.7611 & -4.8483 & 0.0002 \\
RD & 1.3846 & 0.3103 & 4.4611 & 0.0004 \\
ID & 0.7684 & 0.2160 & 3.5563 & 0.0026 \\
\hline \hline
\end{tabular}

Overall, it shows that in South Korea has bilateral trade due to its prominent position in innovation and R\&D. There is huge magnitude to enhance trade and generate positive trade balance. But currently, South Korea's semiconductors is facing a huge challenge due to turmoil in Chinese market. Due to over dependence on trade, this shock is reflecting in plunged economy.

\section{CONCLUSION AND POLICY IMPLICATIONS}

In summary, the ADF and PP tests results show that variables are stationary at I(1) at $10 \%$ and $5 \%$ respectively. Johansen test displays a co-integration rank of one in both trace test and value test at 5\% significance level. Moreover, the Ordinary least squares (OLS) and GMM technique verifies that industrial design and R\&D has a positive impact on high technology exports. So, it shows that innovation plays an important role in enhance country position in international business. Finally, the diagnostic tests confirmed that current OLS model is stable and reliable to use as standard justification.

In addition, the results also highlight various policy implications for South Korean economy. Firstly, Korea ranked as $11^{\text {th }}$ largest economy which has a strong export base and skilled labor force. Based on our result there is positive relationship between technical innovated export and R\&D but due to turmoil in global trade particularly in semiconductors has affected Korean exports. To combat this, Korean government has short term monetary and fiscal policy to support long term growth and trade. International Trade Administration (2020) mentioned that the country has well 
accommodate financial system to manage international transactions mainly attributed by Bank for International Settlement Reserves (BIS). The foreign companies who want partnership with Korea need to invest in joint venture or by having investment in local currency as Korean Won. Moreover, due to current COVID-19 crisis Korean government has introduced vital measures as part of stimulus package to promote exports. Korea International Trade Association developed an online B2B platform for exporters to have remote teleconsulting. Even there are ongoing government efforts to promote bilateral corporation to enhance key export industries in post COVID-19 period (Ministry of Economy and Finance, 2020). But for the long run, to combat the unfavourable demographics and slowing productivity it is vital to have diversified international markets (IMF, 2019b).

Secondly, Global Talent Competitiveness Index (2019) highlighted that Korea has $30^{\text {th }}$ position out of 125 economies with various innovative indicators. Country has a good pool of global knowledge skills rank as $\left(20^{\text {th }}\right)$, with high level skills ranked as $\left(19^{\text {th }}\right)$ and talent impact as $\left(20^{\text {th }}\right)$. Despite high innovative skills country performs particularly poorly with respect to the gender equality indicators. If country succeeded to boost women labor force participation rate it will also generate high productivity. So, there is utmost need to enhance social mobility as an implication of social reform especially women's rights (INSEAD, 2019).

Thirdly, it is suggested that there are utmost efforts to nurture innovation capacities for sustainable economic growth. Even with the forward-looking diversification policies there is an effort to upgrade skills and aging workforce to strengthen the social setup. The decision makers are putting a lot of attention in improving innovation but at the same time the spectrum of growing elderly population is casting negative effects on economy. Actually, this is a vital part to address and Korean government should also take steps to combat elderly poverty rate. Based on our research, we recommend that there can be future studies in South Korean trade diversity by including some other research variables such as patents, innovative exports by products and financial support for innovative projects.

Lastly, South Korean economy has utmost efforts to promote diverse trade and trying to develop, "Free Trade Agreements" with various countries. This element was discussed by Russ and Swenson (2019) that Korea-U.S. Free Trade Agreement (KORUS) can drew U.S. import demand away from other U.S. trading partners. Moreover, there are key sectors such as agriculture, motor vehicles and services which are generating trade balance. But some eco-friendly regulatory reforms further suggested and Korea agreed to take into account some revised terms and conditions with U.S. Above all, to have long run success the rules of KORUS FTA specifically transparency and verification process is vital. Effective policies may turn into ineffective if cold wars and interKorean divisions may not allow government to play a prominent role in various decisions (Schott \& Jung, 2018).

\section{REFERENCES}

Aarikka-Stenroos, L., Aaboen, L., Cova, B., \& Rolfsen, A. (2018). Building B2B relationships via initiation contributors: Three cases from the Norwegian-South Korean international project business. Industrial Marketing Management, 68, 74-85. 
Acemoglu, D., Gancia, G., \& Zilibotti, F. (2012). Competing engines of growth: Innovation and standardization. Journal of Economic Theory, 147(2), 570-601.

Al-Shawaf, A. M. K., \& Almsafir, M. K. (2016). Economic globalization: role of inward and outward FDI with economic growth - evidence from Malaysia. Journal of Business and Retail Management Research, 10(2), 64-74.

Archibugi, D., \& Filippetti, A. (2013). Economic crisis and innovation: Is destruction prevailing over accumulation? Research Policy, 42(2), 303-314.

Auriol, E., Biancini, S., \& Paillacar, R. (2019). Universal Intellectual Property Rights: Too Much of a Good Thing? International Journal of Industrial Organization, 65, 51-81.

Azar, G., \& Ciabuschi, F. (2017). Organizational innovation, technological innovation, and export performance: The effects of innovation radicalness and extensiveness. International Business Review, 26(2), 324-336.

Barbu, A., \& Militaru, G. (2019). The Moderating Effect of Intellectual Property Rights on Relationship between Innovation and Company Performance in Manufacturing Sector. Procedia Manufacturing, 32, 1077-1084.

Bekhet, H. A., \& Al-Smadi, R. W. (2016). The dynamic causality between FDI inflow and its determinants in Jordan. International Journal of Economics and Business Research, 11(1), 26-47.

Bekhet, H. A., \& Mugableh, M. I. (2012). Investigating Equilibrium Relationship between Macroeconomic Variables and Malaysian Stock Market Index through Bounds Tests Approach, International Journal of Economics and Finance, 4(10), 69-81.

Bekhet, H. A., Matar, A., \& Yasmin, T. (2017). Exploring the relationship between $\mathrm{CO}_{2}$ emissions, energy consumption and economic growth in GCC countries: Econometric Analysis. Renewable and Sustainable Energy Reviews, 70, 117-132.

Bekhet, H. A., Othman, N. S., \& Yasmin, T. (2020). Interaction Between Environmental Kuznet Curve and Urban Environment Transition Hypotheses in Malaysia. International Journal of Energy Economics and Policy, 10(1), 384-402.

Bernier, M., Plouffe, M. (2019). Financial innovation, economic growth, and the consequences of macroprudential policies. Research in Economics, 73(2), 162-173.

Boateng, A., Hua, X., Nisar, S., \& Wu, J. (2015). Examining the determinants of inward FDI: Evidence from Norway. Economic Modelling, 47, 118-127.

Bodlaj, M., Kadic-Maglajlic, S., \& Vida, I. (2018). Disentangling the impact of different innovation types, financial constraints and geographic diversification on SMEs' export growth. Journal of Business Research, 108, 466-475. doi:10.1016/j.jbusres.2018.10.043.

Branstetter, L. G., \& Kwon, N. (2018). South Korea's transition from imitator to innovator: The role of external demand shocks. Journal of the Japanese and International Economies, 49, 28-42.

Brooks, C. (2014). Introductory Econometrics for Finance. Cambridge: Cambridge University Press.

Buryi, P., \& Lahiri, S. (2019). Research and development and trade policies for product innovation in the presence of foreign competition. Economic Modelling, 80, 429-440.

Choi, K., Narasimhan, R., \& Kim, S. W. (2016). Opening the technological innovation black box: The case of the electronics industry in Korea. European Journal of Operational Research, 250(1), 192-203.

Cimoli, M., Fleitas, S.\& Porcile, G. (2013). Technological intensity of the export structure and the real exchange rate. Economics of Innovation and New Technology, 22(4), 353-372. 
Coad, A., \& Vezzani, A. (2019). Three cheers for industry: Is manufacturing linked to R\&D, exports, and productivity growth? Structural Change and Economic Dynamics, 50, 1425.

Dai, X., Sun, Z., \& Liu, H. (2018). Disentangling the effects of endogenous export and innovation on the performance of Chinese manufacturing firms. China Economic Review, 50, 42-58.

de Oliveira, J.A.S., Basso, L.F.C., Kimura, H., \& Sobreiro, V.A. (2018). Innovation and financial performance of companies doing business in Brazil. International Journal of Innovation Studies, 2(4), 153-164.

Deligonul, S. D. (2020). Multinational country risk: Exposure to asset holding risk and operating risk in international business. Journal of World Business, 55(2), 101041.

Dizaji, S. F. (2014). The effects of oil shocks on government expenditures and government revenues nexus (with an application to Iran's sanctions), Economic Modelling, 40, 299313.

Doh, S., \& Kim, B. (2014). Government support for SME innovations in the regional industries: The case of government financial support program in South Korea. Research Policy, 43(9), 1557-1569.

Elliot, G., Rothenberg, T. J., \& Stock, J. H. (1996). Efficient tests for an autoregressive unit root Econometrica, 64, 813-836.

Ershova, N. (2017). Investment climate in Russia and challenges for foreign business: The case of Japanese companies. Journal of Eurasian Studies, 8(2), 151-160.

Export.gov. (2019). Korea Manufacturing Technology, Smart Factory. Retrieved from https://www.export.gov/article?id=Korea-Manufacturing-Technology-Smart-Factory

García-Quevedo, J., Segarra-Blasco, A., \& Teruel, M. (2018). Financial constraints and the failure of innovation projects. Technological Forecasting and Social Change, 127, 127-140.

Ghosh, A., Morita, H., \& Nguyen, X. (2018). Technology spillovers, intellectual property rights, and export-platform FDI. Journal of Economic Behavior \& Organization, 151, 171-190.

Gkypali, A., Arvanitis, S., \& Tsekouras, K. (2018). Absorptive capacity, exporting activities, innovation openness and innovation performance: A SEM approach towards a unifying framework. Technological Forecasting and Social Change, 132, 143-155.

Godin, B. (2002). Technological Gaps: Quantitative Evidence and Qualitative Arguments, Technology in Society, 24, 387-413.

Godin, B. (2006). The Linear Model of Innovation: The Historical Construction of an Analytical Framework, Science, Technology, and Human, 31 (6), 639-667.

Godin, B. (2008). In the Shadow of Schumpeter: W. Rupert Maclaurin and the Study of Technological Innovation, Minerva, 46(3), 343-360.

Godin, B. (2010). National Innovation System: A Note on the Origins of a Concept, Working Paper, Project on the Intellectual History of Innovation, Montreal: INRS

Godin, B. (2011). The Linear Model of Innovation: Maurice Holland and the Research Cycle, Social Science Information, 50(3-4), 569-581.

Godin, B. (2012). Innovation Studies: The Invention of a Specialty, Minerva, 50(4), 397-421.

Gujarati, D., \& Porter, D. (2008). Basic econometrics. (5th ed.). New York, USA, McGraw-Hill companies.

Hjalmarsson, E., \& Osterholm, P. (2007). A Residual-Based Cointegration Test for Near Unit Root Variables. SSRN Electronic Journal. doi: 10.2139/ssrn.1066746.

Holcombe, R. G. (2013). South Korea's economic future: Industrial policy, or economic democracy? Journal of Economic Behavior \& Organization, 88, 3-13. 
Hu, M.C., \& Mathews, J.A. (2005). National innovative capacity in East Asia, Research Policy, 34(9), 1322-1349.

Huang, C., \& Hou, T.C. (2019). Innovation, research and development, and firm profitability in Taiwan: Causality and determinants. International Review of Economics \& Finance, 59, 385-394.

Hunt, M. (2019). South Korea commits US\$4bn to bolster tech sectors. Global Government Forum. Retrieved from https://www.globalgovernmentforum.com/south-korea-commits-us4bnto-bolster-tech-sectors/

INSEAD (2019). The Global Talent Competitiveness Index 2019. Retrieved from https://www.insead.edu/sites/default/files/assets/dept/globalindices/docs/GTCI-2019Report.pdf

International Monetary Fund (IMF) (2019a). Korea's Economic Outlook in Six Charts. Retrieved from https://www.imf.org/en/News/Articles/2019/05/16/na052119-koreas-economicoutlook-in-6-charts

International Monetary Fund (IMF) (2019b). Republic of Korea. Retrieved from http://www.imf.org.

International Trade Administration (2020). Korea Methods of Payment. Retrieved from: https://www.trade.gov/knowledge-product/korea-methods-payment

Jiyoung, L., Chulyeon, K., \& Gyunghyun, C. (2019). Exploring data envelopment analysis for measuring collaborated innovation efficiency of small and medium-sized enterprises in Korea. European Journal of Operational Research, 278(2), 533-545.

Johansen, S., \& Juselius, K. (1990). Maximum likelihood estimation and inference on cointegration-with applications to the demand for money. Oxford Bulletin of Economics and Statistics, 52, 169-210.

Kim, H., Shin, J., \& Lee, S. (2019). A new approach to efficient ratio: A case of South Korea's research and development investment. Journal of Engineering and Technology Management, 51, 1-9.

Kishi, K. (2016). Technology Diffusion, Pareto Distribution, and Patent Policy. Discussion Papers No 16-31 in Economics and Business. Osaka University, Toyonaka, Japan.

Kishi, K. (2019). Technology diffusion, innovation size, and patent policy. European Economic Review, 118, 382-410.

Kukharskyy, B. (2020). A tale of two property rights: Knowledge, physical assets, and multinational firm boundaries. Journal of International Economics, 122, 103262.

Larson, J. F., \& Park, J. (2014). From developmental to network state: Government restructuring and ICT-led innovation in Korea. Telecommunications Policy, 38(4), 344-359.

Lechevalier, S., Debanes, P., \& Shin, W. (2019). Financialization and industrial policies in Japan and Korea: Evolving institutional complementarities and loss of state capabilities. Structural Change and Economic Dynamics, 48, 69-85.

Lhermie, G., Tauer, L. W., \& Gröhn, Y. T. (2018). An assessment of the economic costs to the U.S. dairy market of antimicrobial use restrictions. Preventive Veterinary Medicine, 160(15), 63-67.

Lim, J., \& Lee, K. (2019). Employment effect of innovation under different market structures: Findings from Korean manufacturing firms. Technological Forecasting and Social Change, 146, 606-615.

Maclaurin, W. R. (1946). Investing in Science for the future. Technology Review May, 423-454.

Maclaurin, W. R. (1950). The process of technological innovation: The launching of a new scientific industry. American Economic Review, 40, 90-112. 
Makri, K., Theodosiou, M., \& Katsikea, E. (2017). An empirical investigation of the antecedents and performance outcomes of export innovativeness. International Business Review, 26(4), 628-639.

Maradana, R. P., Pradhan, R. P., Dash, S., Zaki, D. B., Gaurav, K., Jayakumar, M., \& Sarangi, A. K. (2019). Innovation and economic growth in European Economic Area countries: The granger causality approach. IMB Management Review, 31(3), 268-282. doi: 10.1016/j.iimb.2019.03.002

Ministry of Economy and Finance (2020). Economic Policies, H2 2020. Retrieved from https://english.moef.go.kr/pc/selectTbPressCenterDtl.do?boardCd=N0001\&seq=4913

Muhammad, B., \& Khan, S. (2019). Effect of bilateral FDI, energy consumption, $\mathrm{CO}_{2}$ emission and capital on economic growth of Asia countries. Energy Reports, 5, 1305-1315.

Nuruzzaman, N., Singh, D., \& Pattnaik, C. (2019). Competing to be innovative: Foreign competition and imitative innovation of emerging economy firms. International Business Review, 28(5), 101490.

Organisation for Economic Cooperation and Development (OECD) (2019). Korea Economic Snapshot. Retrieved from http://www.oecd.org/economy/korea-economic-snapshot/

Patel, P. C., Guedes, M. J., Soares, N., \& Gonçalves, V. C. (2018). Strength of the association between R\&D volatility and firm growth: The roles of corporate governance and tangible asset volatility. Journal of Business Research, 88, 282-288.

Pérez, J. A. H., Geldes, C., Kunc, M. H., \& Flores, A. (2019). New approach to the innovation process in emerging economies: The manufacturing sector case in Chile and Peru. Technovation, 79, 35-55.

Pradhan, R. P., Arvin, M. B., Nair, M., Bennett, S. E., Bahmani, S., \& Hall, J. H. (2018). Endogenous dynamics between innovation, financial markets, venture capital and economic growth: Evidence from Europe. Journal of Multinational Financial Management, 45, 15-34.

Pradhan, R. P., Arvin, M. P., \& Bahmani, S. (2018). Are innovation and financial development causative factors in economic growth? Evidence from a panel granger causality test. Technological Forecasting and Social Change, 132, 130-142.

Putzhammer, M., Slangen, A., Puck, J., \& Lindner, T. (2019). Multinational firms' pace of expansion within host countries: How high rates of pro-market reform hamper the local exploitation of foreign expansion knowledge. Journal of International Management, 26(1), 100703. doi: https://doi.org/10.1016/j.intman.2019.100703.

Rodil, O., Vence, X., \& Sánchez, M. (2016). The relationship between innovation and export behaviour: The case of Galician firms. Technological Forecasting and Social Change, 113(PB), 248-265.

Russ, K. N., \& Swenson, D. L. (2019). Trade Diversion and Trade Deficits: The Case of the KoreaU.S. Free Trade Agreement. Journal of the Japanese and International Economies, 52, 22-31.

Schott, J. J., \& Jung, E. (2018). 18-22 KORUS Amendments: Minor Adjustments Fixed What Trump Called "Horrible Trade Deal", Peterson Institute for International Economics, Retrieved from https://www.piie.com/system/files/documents/pb18-22.pdf

Schumpeter, J. A. (1934). The Theory of Economic Development. Cambridge: Harvard University Press.

Seo, B. K., \& Joo, Y. (2019). Innovation or episodes? Multi-scalar analysis of governance change in urban regeneration policy in South Korea. Cities, 92, 27-35. 
Silva, G. M., Gomes, P. J., \& Lages, L. F. (2019). Does importer involvement contribute to product innovation? The role of export market factors and intra-firm coordination. Industrial Marketing Management, 78, 169-182.

Singhai, S. (2019). A report on WIPO-CNIPA Training Course on Management and Commercialization of Intellectual Property Assets. World Patent Information, 57, 35-37.

Štěrbová, M., Stojanovski, V., Weiss, G., \& Šálka, J. (2019). Innovating in a traditional sector: Innovation in forest harvesting in Slovakia and Macedonia. Forest Policy and Economics, 106, 101960.

Švarc, J., Lažnjak, J., \& Dabić, M. (2019). Regional innovation culture in innovation laggard: A case of Croatia. Technology in Society, 58, 101123.

The United Nations Conference on Trade and Development (UNCTAD) (2019a). Trade and Development Report 2019. United Nations Publication, ISSN: 0255-4607; eISSN: 22253262

The United Nations Conference on Trade and Development (UNCTAD) (2019b). Digital Economy Report, 2019. United Nations Publication, ISSN 2664-2255, eISSN 2664-2263.

Zhu, X., Zheng, W., Zhang, H., \& Guo, Y. (2019). Time-varying international market power for the Chinese iron ore markets. Resources Policy, 64, 101502. 